\title{
Meningkatkan pengetahuan dan perilaku pencegahan COVID-19 maternal neonatal, melalui pendidikan kesehatan secara online : studi pada ibu hamil
}

\author{
Diki Retno Yuliani ${ }^{1 *}$, Riza Amalia ${ }^{2}$ \\ ${ }_{1,2}$ Poltekkes Kemenkes Semarang, Indonesia.
}

\begin{tabular}{l}
\hline INFORMASI ARTIKEL: \\
\hline Riwayat Artikel: \\
Tanggal diterima: 12-Agustus-2020 \\
Tanggal direvisi: 12-November-2020 \\
Tanggal dipublikasi: 31-Desember-2020 \\
\hline Kata kunci: \\
Pengetahuan \\
Perilaku \\
Pencegahan COVID-19 maternal neonatal \\
Pendidikan kesehatan online \\
Ibu hamil
\end{tabular}

\subsection{6/jrki.v4i2.134}

Key word : Knowledge Behavior Maternal neonatal COVID-19 prevention Online health education Pregnant woman

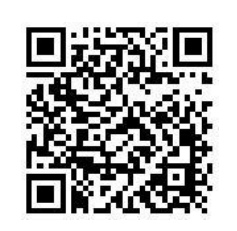

\begin{abstract}
ABSTRAK
Latar belakang: COVID-19 berdampak pada pembatasan layanan kesehatan maternal dan neonatal, termasuk penyampaian informasi kesehatan tentang pencegahan COVID-19 pada maternal. Tujuan penelitian: Mengetahui pengaruh pendidikan kesehatan pencegahan COVID-19 maternal secara online terhadap pengetahuan dan perilaku ibu hamil. Metode: Desain penelitian adalah penelitian non equivalent pretest posttest group desain. Sampel adalah 28 ibu hamil di kecamatan Baturraden dengan teknik cluster sampling. Instrumen yang digunakan adalah kuesioner pengetahuan dan kuesioner perilaku. Uji statistik yang digunakan adalah paired t-tets. Hasil: Ada perbedaan mean pretest dan posttest pada kelompok intervensi. Simpulan: Ada pengaruh pendidikan kesehatan pencegahan COVID-19 bagi maternal neonatal secara online terhadap pengetahuan dan perilaku ibu hamil.
\end{abstract}

Background: COVID-19 has an impact on maternal and neonatal health care restrictions, including the delivery of health information about COVID19 prevention in maternal. Objective: The purpose of this study was to find out the effect of maternal COVID-19 prevention health education online on the knowledge and behavior of pregnant women. Methods: This study used non equivalent research pretest posttest group design. The sample were 28 pregnant women in Baturraden sub-district with cluster sampling techniques. Instruments used are knowledge questionnaires and behavioral questionnaires. The statistical test used is paired t-tets. Results: There were differences in mean pretest and posttest in the intervention group. Conclusion: In conclusion, there is an influence of online health education of maternal COVID-19 prevention on the knowledge and behavior of pregnant women.

\section{Pendahuluan}

Angka Kematian Ibu (AKI) merupakan rasio kematian ibu selama masa kehamilan, persalinan dan nifas per 100.000 kelahiran hidup, yang disebabkan oleh kehamilan, persalinan dan nifas atau penatalaksanaannya, dan bukan disebabkan oleh penyebab lain seperti kecelakaan. Secara umum, sejak tahun 1991- 2015, kematian ibu mengalami penurunan dari 390 menjadi 305 per

\footnotetext{
* Korespondensi penulis.

Alamat E-mail: dikiretnoyuliani@gmail.com
}

100.000 kelahiran hidup. Walaupun terjadi kecenderungan penurunan angka kematian ibu, namun pada tahun 2015 , belum berhasil mencapai target MDGs yaitu sebesar 102 per 100.000 kelahiran hidup pada tahun 2015. (Kementrian Kesehatan RI, 2019).

Pada kondisi normal, kematian ibu masih menjadi tantangan besar di Indonesia, apalagi pada situasi bencana. Saat ini, Indonesia sedang menghadapi pandemic COVID-19, yang telah ditetapkan sebagai bencana nasional non alam. Hal tersebut menyebabkan pelayanan kesehatan maternal dan neonatal menjadi salah satu layanan yang terdampak secara akses maupun kualitas. 
Dikhawatirkan, hal tersebut dapat menyebabkan peningkatan morbiditas dan mortalitas ibu dan bayi baru lahir (Direktorat Kesehatan Keluarga, 2020).

COVID-19 adalah penyakit yang disebabkan oleh virus corona jenis baru yang dapat menyebabkan timbulnya pneumonia. Angka kejadian COVID-19 di dunia cenderung naik dari waktu ke waktu, termasuk di Indonesia. Pandemic COVID-19 telah menelan banyak korban jiwa, memberikan dampak kerugian material yang sangat besar serta berimplikasi pada aspek ekonomi, sosial dan kesejahteraan masyarakat (Presiden RI, 2020). Oleh karena itu, diperlukan upaya pencegahan untuk mengendalikan penularan COVID-19, diantaranya dengan menjaga jarak aman minimal 1 meter, menggunakan masker sesuai kondisi (masker kain atau masker medis), mencuci tangan dengan sabun atau menggunakan handsanitizer, mengkonsumsi gizi seimbang, meningkatkan aktifitas fisik dan sebagainya. Upaya-upaya tersebut harus di terapkan secara rutin dalam kehidupan sehari-hari oleh semua lapisan masyarakat termasuk ibu hamil.

Sebuah studi memberikan bukti pentingnya dan urgensi pendidikan kesehatan tentang COVID19. Upaya pemberian pendidikan kesehatan untuk meningkatkan kesadaran kesehatan masyarakat terhadap penyakit menular adalah hal yang sangat dibutuhkan, terutama untuk beberapa kelompok rentan (Li et al., 2020). Ibu hamil adalah salah satu kelompok yang rentan terhadap infeksi, karena secara alamiah sistem kekebalan tubuh ibu turun sehingga meningkatkan risiko komplikasi yang lebih berat (Wu et al., 2020).

Pandemi COVID-19 menyebabkan berbagai pembatasan ke sebagian besar layanan rutin termasuk pembatasan pada pelayanan kesehatan maternal dan neonatal, misalnya anjuran menunda pemeriksaan kehamilan, anjuran menunda kelas ibu hamil serta ibu hamil menjadi enggan datang ke fasiltas pelayanan kesehatan lainnya karena takut tertular (Direktorat Kesehatan Keluarga, 2020). Hal tersebut dapat menyebabkan penyampaian informasi tentang kesehatan termasuk upaya pencegahan COVID-19 pada ibu hamil kurang memadai.

Untuk meminimalkan dampak pembatasan akses pelayanan maternal neonatal terhadap kesehatan ibu, janin dalam kandungan atau bayi saat sudah dilahirkan, serta sebagai upaya pencegahan COVID-19 selama menjalani masa kehamilan, persalinan, nifas menyusui dan bayi baru lahir, dapat dilakukan upaya merubah penyampaian materi tentang pencegahan COVID19 bagi maternal neonatal dari penyampaian informasi atau pendidikan kesehatan secara tatap muka menjadi online. Tujuan studi ini untuk mengetahui pengaruh pendidikan kesehatan pencegahan COVID-19 maternal neonatal secara online terhadap pengetahuan dan perilaku ibu hamil.

\section{Metode penelitian}

Desain penelitian yang digunakan adalah penelitian non equivalent pretest posttest group desain. Populasi target dalam penelitian ini adalah ibu hamil di Kabupaten Banyumas, populasi terjangkau adalah ibu hamil di Kecamatan Baturraden, Kabupaten Banyumas. Sampel Penelitian ini adalah 30 ibu hamil di wilayah kerja Puskesmas Baturraden II, 15 ibu hamil sebagai kelompok intervensi dan 15 ibu hamil sebagai kelompok kontrol. Selama proses penelitian, dua responden ibu hamil kelompok kontrol dropout, sehingga total responden 28 orang.

Penelitian ini menggunakan teknik pengambilan sampel cluster. Responden diambil dari dua desa di wilayah kerja Puskesmas II Baturraden dengan jumlah ibu hamil relatif banyak. Kriteria inklusi dalam penelitian ini adalah ibu hamil yang bersedia mengikuti penelitian secara online, kriteria eksklusi adalah ibu hamil yang tidak memiliki android, tidak memiliki Whatsapp dan tidak bisa akses google form.

Instrumen penelitian adalah kuesioner pengetahuan dan perilaku. Kuesioner pengetahuan terdiri dari 30 item pertanyaan, dengan pilihan jawaban salah dan benar. Kuesioner pengetahuan pertanyaan tentang 
prinsip umum pencegahan COVID-19, pencegahan COVID-19 pada ibu hamil, bersalin, nifas, menyusui dan bayi baru lahi. Kuesioner perilaku terdiri dari 38 item pertanyaan dengan pilihan jawaban tidak pernah, kadang-kadang, sering dan selalu. Kuesioner perilaku berisi pertanyaan tentang prinsip umum pencegahan COVID-19 dan pencegahan COVID-19 pada ibu hamil. Uji validitas instrumen melalui telaah pakar.

Penelitian dilaksanakan pada bulan Oktober-November 2020. Data dikumpulkan melalui pengisian google form biodata responden dan kuesioner pengetahuan dan perilaku tentang pencegahan COVID-19 pada maternal. Pada minggu pertama responden diminta untuk mengisi form persetujuan menjadi responden dan mengisi biodata, kemudian responden dimasukkan ke dalam grup Whatsapp sesuai kelompok masingmasing. Pada minggu ke dua sampai ke empat responden diminta untuk mengisi kuesioner pretest, memperoleh materi video tiga kali, mendapatkan buku materi dan mengisi kuesioner posttest. Link google form dan video di bagikan melalui grup whatsapp. Materi video pertama adalah prinsip umum pencegahan COVID-19, materi video kedua adalah pencegahan COVID-19 pada ibu hamil dan bersalin, materi video ketiga adalah pencegahan COVID-19 pada ibu nifas, menyusui dan bayi baru lahir.

Analisis data menggunakan uji paired t-test untuk menguji perbedaan mean pretest dan posttest. Ethical clerence diajukan pada komisi etik penelitian Poltekkes Kemenkes Semarang melalui http://sim-epk.keppkn.kemkes.go.id/ dan disetujui tanggal 20 Oktober 2020.

\section{Hasil dan Pembahasan}

Responden dalam penelitian ini sejumlah 28 orang. Data Karakteristik responden berdasarkan Usia, Pendidikan, Pekerjaan, Jarak Kehamilan dan Perkawinan disajikan pada Tabel 1.

Tabel 1. Distribusi frekuensi Karakteristik Responden

\begin{tabular}{|c|c|c|}
\hline \multirow[t]{2}{*}{ Parameter } & \multicolumn{2}{|c|}{ Frekuensi } \\
\hline & $\mathbf{N}$ & $\%$ \\
\hline \multicolumn{3}{|l|}{ Usia } \\
\hline$<20$ tahun & 0 & 0 \\
\hline 20-35 tahun & 24 & 86 \\
\hline$>35-40$ th & 4 & 14 \\
\hline Total & 28 & 100 \\
\hline \multicolumn{3}{|l|}{ Pendidikan } \\
\hline SD & 3 & 11 \\
\hline SMP & 7 & 25 \\
\hline SMA/SMK & 16 & 57 \\
\hline PT & 2 & 7 \\
\hline Total & 28 & 100 \\
\hline \multicolumn{3}{|l|}{ Pekerjaan } \\
\hline PNS & 0 & 0 \\
\hline Karyawan & 3 & 11 \\
\hline Swasta & 1 & 4 \\
\hline Ibu rumah tangga & 22 & 78 \\
\hline Lain-lain & 2 & 7 \\
\hline Total & 28 & 100 \\
\hline \multicolumn{3}{|l|}{ Jarak kehamilan } \\
\hline Hamil pertama & 11 & 39 \\
\hline$<2$ tahun & 2 & 7 \\
\hline $2-5$ tahun & 9 & 32 \\
\hline$>5-10$ tahun & 6 & 22 \\
\hline Total & 28 & 100 \\
\hline \multicolumn{3}{|l|}{ Perkawinan } \\
\hline Pertama & 27 & 96 \\
\hline Kedua & 1 & 4 \\
\hline Total & 28 & 100 \\
\hline
\end{tabular}

Karakteristik responden mayoritas memiliki usia 20-35 tahun, pendidikan SMA, pekerjaan ibu rumah tangga, hamil pertama dan perkawinan pertama. 
Tabel 2. Distribusi frekuensi pengetahuan dan perilaku ibu hamil

\begin{tabular}{lccccc}
\hline \multicolumn{2}{c}{ Parameter } & \multicolumn{2}{c}{ Pengetahuan } & \multicolumn{2}{c}{ Perilaku } \\
& & Pre & Post & Pre & Post \\
\hline Kelompok & Mean & 20,53 & 24,47 & 74 & 79,73 \\
Intervensi & IK $95 \%$ & $19,16-$ & $22,44-$ & $68,92-$ & $74,31-$ \\
(n=15) & & 21,90 & 26,49 & 79,08 & 85,16 \\
& SD & 2,47 & 3,66 & 9,17 & 9,80 \\
& Min & 17 & 19 & 58 & 64 \\
& Maks & 26 & 30 & 91 & 94 \\
Kelompok & & & & & \\
Kontrol & Mean & 21 & 21,31 & 76,23 & 75,92 \\
(n=13) & IK 95\% & $19,44-$ & $19,82-$ & $69,43-$ & $70,42-$ \\
& & 22,56 & 22,80 & 83,03 & 81,43 \\
& SD & 2,58 & 2,46 & 11,26 & 9,11 \\
& Min & 17 & 18 & 63 & 62 \\
& Maks & 25 & 27 & 94 & 95 \\
\hline
\end{tabular}

Keterangan tabel : IK = interval kepercayaan; SD = standar deviasi

Mean pengetahuan kelompok intervensi dan kelompok kontrol mengalami penambahan dari skor pretest ke posttest, namun penambahan mean kelompok intervensi 12 kali penambahan mean kelompok kontrol. Untuk mean perilaku kelompok intervensi naik dari pretest ke posttest, sedangkan mean perilaku kelompok kontrol turun.

Pengetahuan ibu hamil tentang upaya pencegahan COVID-19 maternal neonatal pada kelompok intervensi, mean pretest 20,53 dan mean posttest 24,47 dari skor total 30 . Sehingga persentase tingkat pengetahuan ibu hamil pada kelompok intervensi adalah $68 \%$ untuk pretest dan $82 \%$ untuk posttest. Peningkatan pengetahuan ibu hamil tentang pencegahan COVID-19 maternal neonatal tersebut sesuai dengan studi yang melaporkan bahwa setelah diberikan penyuluhan, pengetahuan ibu hamil tentang pencegahan penularan COVID-19 selama kehamilan meningkat dari $21 \%$ menjadi $89 \%$ ibu dengan pengetahuan baik (Aritonang, Nugraeny and Siregar, 2020).

Pada kelompok kontrol, pengetahuan ibu hamil tentang upaya pencegahan COVID-19 maternal neonatal, mean pretest 21 dan mean posttest 21,31 dari skor total 30 . Sehingga persentase tingkat pengetahuan ibu hamil pada kelompok kontrol adalah $70 \%$ untuk pretest dan $71 \%$ untuk posttest.

Data pengetahuan pada kedua kelompok sebelum diberikan pendidikan kesehatan menunjukkan bahwa, pengetahuan ibu hamil tentang pencegahan COVID-19 maternal neonatal sudah cukup baik, dengan rata-rata keduanya adalah $69 \%$. Hal ini sesuai dengan studi yang melaporkan bahwa pengetahuan ibu hamil tentang tindakan pencegahan terhadap COVID-19, $60 \%$ dinilai memadai, yaitu memiliki nilai pengetahuan atau mampu menjawab benar $\geq 65 \%$ (Nwafor et al., 2020). Studi lain juga melaporkan hal yang sama, yaitu mayoritas ibu hamil memiliki pengetahuan yang memadai tentang COVID-19 (Anikwe et al., 2020).

Hasil penelitian menunjukkan bahwa perilaku ibu hamil kelompok intervensi tentang pencegahan COVID-19 maternal neonatal, diperoleh nilai mean pretest 74 dan nilai mean posttest 79,73 dengan skor maksimal 114 . Artinya persentase perilaku ibu hamil kelompok intervensi, pada pretest dan posttest adalah $65 \%$ dan $70 \%$. Sedangkan perilaku pada kelompok kontrol, diperoleh nilai mean pretest 76,23 dan nilai mean posttest 75,92 dengan skor maksimal 114. Artinya persentase perilaku ibu hamil kelompok kontrol tentang pencegahan COVID-19 maternal neonatal adalah $67 \%$ pada pretest dan posttest.

Hasil tersebut menunjukkan bahwa perilaku ibu hamil sebelum diberikan pendidikan kesehatan pencegahan COVID-19 maternal neonatal dalam kategori cukup baik, yaitu $66 \%$. Hal tersebut sesuai dengan studi yang melaporkan bahwa mayoritas ibu hamil menunjukkan pengetahuan, sikap dan praktik pencegahan COVID-19 yang baik (Anikwe et al., 2020).

Hasil tersebut tidak sesuai dengan sebuah studi yang melaporkan bahwa mayoritas ibu hamil memiliki pengetahuan yang memadai tentang tindakan pencegahan terhadap infeksi COVID-19, namun untuk praktik tindakan pencegahan masih buruk. Studi tersebut dilaksanakan pada ibu hamil dengan sumber daya rendah (Nwafor et al., 2020), sedangkan pada penelitian ini pemilihan responden tidak mempertimbangkan sosial ekonomi. 
Tabel 3. Hasil Uji Paired T-Test (Uji beda skor pretest dengan posttest)

\begin{tabular}{lccc}
\hline \multicolumn{2}{c}{ Parameter } & Pengetahuan & Perilaku \\
\hline Kelompok & Mean & $-3,93$ & $-5,73$ \\
Intervensi & SD & 3,12 & 9,93 \\
$(n=15)$ & SE & 0,82 & 2,56 \\
& IK 95\% & $(-5,69)-(-2,18)$ & $(-11,23)-(-0,23)$ \\
& Nilai p & $0,000^{* *}$ & $0,042^{*}$ \\
Kelompok & Mean & $-0,31$ & 0,31 \\
Kontrol & SD & 2,02 & 6,13 \\
$(n=13)$ & SE & 0,56 & 1,70 \\
& IK 95\% & $(-1,53)-0,91$ & $(-3,40)-4,01$ \\
& Nilai p & 0,592 & 0,859 \\
\hline
\end{tabular}

$\mathrm{SD}=$ standar deviasi; $\mathrm{SE}=$ standar eror; $\mathrm{IK}=$ interval kepercayaan; * nilai $p<0.05 ;{ }^{* *}$ nilai $p<0,01$; tanda negatif $(-)$ pada mean = adanya penambahan nilai dari pretest ke posttest.

Nilai p pada pengetahuan dan perilaku kelompok intervensi $<0,05$. Artinya ada perbedaan mean pengetahuan dan perilaku kelompok intervensi sebelum dan sesudah diberikan pendidikan kesehatan.

Hasil uji statistik dengan paired t-test diperoleh ada perbedaan mean pengetahuan pretest dengan posttest pada kelompok intervensi, sedangkan pada kelompok kontrol tidak ada perbedaan mean pengetahuan pretest dengan posttest. Artinya ada pengaruh pendidikan kesehatan tentang pencegahan COVID-19 maternal neonatal terhadap pengetahuan ibu hamil.

Sebuah studi melaporkan bahwa ibu hamil yang mendapatkan pendidikan gizi dan pesan gizi, pengetahuan dan perilaku minum zat besi mengalami peningkatan (Kusfriyadi, Hadi and Fuad, 2012). Salah satu tujuan dari pendidikan kesehatan adalah responden dapat mengetahui dan memahami upaya-upaya yang dapat dilakukan untuk mengatasi masalah yang mereka hadapi, dengan memanfaatkan sumber daya yang mereka miliki dan ditunjang dengan dukungan dari luar (Mubarak and Chayatin, 2009). Pengetahuan didefinisikan sebagai hasil pengindaraan manusia atau hasil tahu seseorang terhadap suatu obyek melalui indra yang dimilikinya meliputi mata, hidung, telinga, dan sebagainya, namun sebagian besar melalui indra penglihatan dan pendengaran (Notoatmodjo, 2010).

Dalam penelitian ini, pendidikan kesehatan diberikan secara online dengan share video melalui grup whatsapp dan pengiriman modul kepada responden. Video berisi materi tentang prinsip umum pencegahan COVID-19, pencegahan COVID19 pada kehamilan, persalinan, nifas, menyusui dan bayi baru lahir. Sedangkan buku, berisi materi yang sama dengan video, dengan penjelasannya. Sebuah studi melaporkan bahwa setelah menerima inovasi secara daring tentang terapi warfin, responden mengalami peningkatan pengetahuan dan kepatuhan pasien dengan ratarata 90\%. Sebanyak 237 responden yang dirangkum dalam review tersebut menerima pendidikan warfarin melalui video menggunakan berbagai perangkat elektronik (Faizah, Sinuraya and Putriana, 2020).

Hasil studi lain melaporkan bahwa, terdapat perbedaan pengetahuan dan sikap ibu hamil antara sebelum dan sesudah diberikan pendidikan kesehatan tentang ASI dan menyusui dengan metode multimedia, dan ada perbedaan metode multimedia dengan metode tatap muka dalam meningkatkan pengetahuan dan sikap tentang ASI dan menyusui pada ibu hamil (Hapitria and Padmawati, 2017).

Hasil uji statistik dengan paired t-test diperoleh ada perbedaan mean perilaku pretest dengan posttest pada kelompok intervensi, sedangkan pada kelompok kontrol tidak ada perbedaan mean perilaku pretest dengan posttest. Ada pengaruh pendidikan kesehatan tentang pencegahan COVID-19 maternal neonatal terhadap perilaku ibu hamil.

Sebuah studi melaporkan ada pengaruh pendidikan kesehatan dan SMS reminder terhadap kepatuhan ibu hamil dalam mengkonsumsi tablet besi (Lestari, 2015). Studi lain memberikan bukti pentingnya dan urgensi pendidikan kesehatan tentang COVID-19. Upaya meningkatkan pendidikan kesehatan untuk meningkatkan kesadaran kesehatan masyarakat terhadap penyakit menular adalah hal yang sangat dibutuhkan, terutama untuk beberapa kelompok rentan. Hal yang perlu dipertimbangkan adalah informasi dari media sosial tidak selalu dapat diandalkan, masyarakat termasuk orang tua harus memperoleh informasi dari situs resmi pihak berwenang seperti WHO dan Pusat Pengendalian Penyakit nasional, atau dari sumber lain yang didukung oleh otoritas, daripada dari pencarian umum internet atau media sosial (Li et al., 2020). Ibu hamil adalah salah satu kelompok yang rentan terhadap infeksi, karena secara alamiah sistem kekebalan tubuh ibu turun sehingga meningkatkan risiko komplikasi yang lebih berat (Wu et al., 2020).

Perubahan perilaku kesehatan yang disebabkan oleh pendidikan, promosi atau kesehatan diawali dengan pemberian informasi 
tentang pola hidup sehat, yang akan meningkatkan pengetahuan masyarakat tentang hal tersebut. Selanjutnya dengan pengetahuan tersebut akan menimbulkan kesadaran mereka dan pada akhirnya menyebabkan masyarakat berperilaku sesuai dengan pengetahuan yang mereka miliki (Notoatmodjo, 2010).

\section{Simpulan}

Kesimpulan dari studi ini adalah pendidikan kesehatan pencegahan COVID-19 maternal neonatal secara on line dapat berpengaruh terhadap pengetahuan dan perilaku ibu hamil.

\section{Ucapan terima kasih}

Ucapan terima kasih kami sampaikan kepada Kepala Dinas Kesehatan Kabupaten Banyumas dan Kepala Puskesmas Baturraden II Dan jajarannya yang telah memberikan ijin dalam pelaksanaan penelitian serta Poltekkes Kemenkes Semarang yang telah memberikan pembiayaan penelitian.

\section{Daftar Pustaka}

Anikwe, C. C. et al. (2020) 'Coronavirus disease 2019: Knowledge, attitude, and practice of pregnant women in a tertiary hospital in Abakaliki, southeast Nigeria', International Journal of Gynecology \& Obstetrics. Wiley Online Library.

Aritonang, J., Nugraeny, L. and Siregar, R. N. (2020) 'Peningkatan Pemahaman Kesehatan pada Ibu hamil dalam Upaya Pencegahan COVID19', Jurnal Solma, 9(2), pp. 261-269.

Direktorat Kesehatan Keluarga (2020) 'Pedoman Bagi Ibu Hamil, Ibu Nifas, dan Bayi Baru Lahir Di Era Pandemi Covid-19', pp. 9-12. Available at:

http://www.kesga.kemkes.go.id/images/ped oman/Pedoman bagi Ibu Hamil, Bersalin, Nifas dan BBL di Era Pandemi COVID 19.pdf.

Faizah, U. R., Sinuraya, R. K. and Putriana, N. A. (2020) 'Efektivitas Edukasi Daring dalam Terapi Warfarin terhadap Kepatuhan Pasien', Majalah Farmasetika, 5(5), pp. 233-244.

Hapitria, P. and Padmawati, R. (2017) 'Efektifitas Pendidikan Kesehatan Melalui Multimedia dan Tatap Muka terhadap Pengetahuan dan Sikap Ibu Hamil tentang ASI dan Menyusui', Care: Jurnal IImiah IImu Kesehatan, 5(2), pp. 156-167.

Kementrian Kesehatan RI (2019) Profil Kesehatan Indonesia 2018 Kemenkes RI. Jakarta: Kemnenkes RI. Available at: http://www.depkes.go.id/resources/downloa d/pusdatin/profil-kesehatan-indonesia/Datadan-Informasi_Profil-Kesehatan-Indonesia2018.pdf.

Kusfriyadi, M. K., Hadi, H. and Fuad, A. (2012) 'Pendidikan gizi dan pesan gizi melalui short message service terhadap pengetahuan, perilaku, dan kepatuhan ibu hamil minum tablet besi', Jurnal Gizi Klinik Indonesia, 9(2), pp. 87-96.

Lestari, D. D. (2015) 'Pengaruh Pendidikan Kesehatan dan SMS Reminder Terhadap Kepatuhan Ibu Hamil dalam Mengkonsumsi Tablet Besi di Wilayah Kerja Puskesmas Pisangan'. Jakarta: Fakultas Kedokteran dan Ilmu Kesehatan UIN Syarif Hidayatullah, 2015.

Li, W. et al. (2020) 'Public health education for parents during the outbreak of COVID-19: a rapid review', Annals of translational medicine. AME Publications, 8(10).

Mubarak, W. I. and Chayatin, N. (2009) 'Ilmu kesehatan masyarakat: teori dan aplikasi', Jakarta: Salemba Medika, 393.

Notoatmodjo, S. (2010) 'Ilmu Perilaku Kesehatan, Penerbit Rineka Cipta', Jakarta.

Nwafor, J. I. et al. (2020) 'Knowledge and practice of preventive measures against COVID-19 infection among pregnant women in a lowresource African setting', medRxiv. Cold Spring Harbor Laboratory Press.

Presiden RI (2020) Keputusan Presiden Republik Indonesia No 7 Tahun 2020 Tentang Gugus Tugas Percepatan Penananan Covid-19. Indonesia.

Wu, Y. et al. (2020) 'Perinatal depressive and anxiety symptoms of pregnant women along with COVID-19 outbreak in China', American Journal of Obstetrics and Gynecology. Elsevier. 